\title{
Enhancing Miner's Commitment through Corporate Social Responsibility: Evidence of the Mining Sector
}

\begin{abstract}
* Email address: gbahizire@stmail.ujs.edu.cn

Several studies have assessed the different dimensions of corporate social responsibility (CSR), literatures have been emerging in studying the impact of CSR in different sectors. Few are looking at its effect inside the organization, such as its effects on the workers. Therefore this research aims to investigate the dimensions of CSR within the mining sector and its effect on the organizational commitment. The proposed model was tested on a sample of 415 employees within the mining sector of the Democratic Republic of CONGO. Statics techniques and tools were used in this research such as a linear regression model in determining the linear relationship between the dimensions of CSR and the commitment, regression path analysis using Lisrel to show the strength of the relationship. The findings revealed that 3 dimensions of CSR (economic, legal and environmental) were significant predictors of organizational commitment. Management within the mining sector of DRC, ought to recognize the fact that workers who perceive good social responsibility of their organizations, develop emotional attachment and sense of obligation to their organization and are most likely to be committed to the organization, workers had neutral perceptions about the Philanthropic activities of the mining firms and this dimension was insignificant.

Keywords: Corporate Social Responsibility, Mining Sector, Employees, Organizational Commitment.
\end{abstract}

Grace Mulindwa Bahizire ${ }^{1 *}$, Li FangLin ${ }^{2}$, Thierry Rukind Mujimb ${ }^{3}$

1. School of Finance and Economics, Jiangsu University, 212000, Zhenjiang China;

2. School of Finance and Economics, Jiangsu University, 212000, Zhenjiang China,

3. School of Management, Jiangsu University 212000, Zhenjiang, China,

DOI: $10.7176 / \mathrm{JESD} / 11-20-13$

Publication date:October $31^{\text {st }} 2020$

\section{Introduction}

A growing body of researches has emerged in relationship between the corporate social responsibility and organizations, whereby a quite good number of empirical studies have focused on investigating the impacts of CSR on the firm performance, financial performance (Herrera Madueño, Larrán Jorge, Martínez Conesa, and Martínez-Martínez, 2016; Maqbool and Zameer, 2018; Rodriguez-Fernandez, 2016). Meanwhile few researches have studied on how CSR would influence employee within an organization, considering the few studies, which have examined the corporate social activities affecting employees. Various factors were considered such as employees' behavior at work, employee attitudes (Fanglin, Bahizire, and Benjamin, 2019; Glavas and Kelley, 2015) .This research is focusing on CSR as enhancer of miner's commitment within the DRC mining sector, Similarly (Bouraoui, Bensemmane, Ohana, and Russo, 2019; Stephen Brammer, Andrew Millington, and Bruce Rayton, 2007; Peterson, 2004) have looked on CSR influencing the organizational commitment, the authors considered different sectors others than mining sector and different countries, whereas, it's obvious that factors across countries vary, and the implementation of corporate social responsibility may differ from emerging economies to developed countries, however results might be also different, in this regards, it's important to conduct an empirical research within different contexts, different sectors, such as new industry, new economic environment, therefore investigating this relationship, mining sector was considered in an emerging economy of Democratic Republic of Congo.

Few studies have looked at the impact of the DRC mining sector in term of sustainability and economic development (Garrett and Lintzer, 2010;Geenen, 2014), DRC is the world's largest producer of several minerals such as cobalt. The country holds more than half of the world's cobalt reserves according to the US Geological Survey. Moreover, the country produces large quantities of copper, diamonds, gold, oil, tin, tantalum, tungsten and zinc. And also, one of the world's leading producers of diamonds. Considering the Specific legal or regulatory measures that are in place, seeking to enforce the implementation of the distinctive dimensions of the Corporate Social responsibility, as the mining firms have been struggling to overcome certain social and legal issues, such as labors well-being, environmental devastation. 
In regards to this, various firms have been trying, to effectively integrate the CSR activities, by following the national, regional and international transparency standards, traceability and certification of mineral substances, including the disclosure and publication of contracts and actual beneficiaries of mining assets as well as declarations of all taxes, duties and fees due and paid to the State.as well as the declarations of all taxes, fees and royalties due and paid to the State by the new mining code in line with the Extractive Industry transparency Initiative. Thus, in the mining sector, CSR is expected to balance the diverse needs of communities and the organizations to protect the environment without ignoring the primary objective of the business, which is to make profit. It involves identifying the needs and interests of the different stakeholders, so a balance can be considered in the business strategies. The concept of CSR is a means by which companies can frame their attitudes and strategies towards, and enhance relationship with stakeholders, such as investors, employees or, communities, within a popular and acceptable concept. (Jenkins 2003)

When it comes to the impacts causing by the sector in the environment and society, Mining sector portrays an evil image, major consequences such as devastation, and mining operations won't cease in particular area until this area gets exhausted with all of its resources. Generally, the damages caused by this sector have been always covered by referring to the cost-benefit theory stating that the physical damage in this mining area is compensate with the overall financial benefits. However, by looking at the negative impacts of mining, school of thoughts have explored the implication of corporate social responsibility with this sector, Whereby implementing effectively the CSR practices in the extractive sector has raised so many questions from researchers, there is a gap between the CSR programs and their real life impact in the environment and in the society (Frynas, 2005). Although Considerable efforts have been made by the industry to highlight its commitment to both protecting the environment and addressing the needs.

(Campbell, 2012) agrees with the School of thought, who believed that government bodies and institutions have a big role to play in solving the issues of the mining sectors Vis a Vis of their stakeholders, whereby firms engaging CSR into their strategies, will not be enough to solve the problem of mining, the governments need to play the role as regulators in this sector, in order to enforce good conducts. Meanwhile a country such as Democratic Republic of Congo as well some other countries in Africa, it has been noted that such countries have weakened governance in this sector due to dysfunctional administrative and political stabilities. Therefore, for improving this sector the governance gaps would have to be addressed. At the other side, another school of thought believe that firms have the key role to play in this sector, however in their researches they have tended in exploring the impact CSR strategies that firms have been implementing in enhancing the conditions within this sector. Very few studies have looked at the adaptability of Carol's Pyramid into the Mining sector,(Andrews, 2016; Mutti, Yakovleva, Diego, and Di Marco, 2012; Rodrigues and Mendes, 2018).

Employees, being considered as one of the most important internal resource, require special attention, due to their key role. There is an emergent need for good corporate governance and social responsibility in the mining sector, whereby the policy makers in the DRC will need to enforce regulations in mining sector for the well-being of workers. There is no doubt about the importance of the mining sector in the economy of DRC. The sector is significantly affecting the environment in a negative way, and also has a tremendous negative impact on the society furthermore the employees. As the People working in the mines are exposed to various physical, chemical, mechanical, biological, and psychosocial risk factors, Child labor is the DRC common issue in this sector, and the mining industry is no exception. More over Mining of Certain minerals can cause health problems for women and children who work in the mines. Thus, the well-being of workers has significant connection with the performance of employee at work. Whereas the well-being of employee in this sector, is a Challenge and a serious question that needs to be addressed, however this study is aiming to assess how socially responsible strategy will contribute to the employee Commitment.

This study seeks to address the research gap on CSR and employee organizational behavior by looking at the relationship between employees' perceptions of CSR and Organizational commitment, in line to this, certain researchers found that CSR is related to employee commitment, and whereby commitment in itself is therefore a good predictor of performance. 
However This study explored these prior researches such as (Asrar-ul-Haq, Kuchinke, and Iqbal, 2017; S Brammer, A Millington, and B Rayton, 2007; Closon, Leys, and Hellemans, 2015; Kim, Song, and Lee, 2016; Roudaki and Arslan, 2017; Shin, Hur, and Kang, 2016) in investigating the effects of CSR on Organizational Commitment. Whereof the purpose of this study is to examine the employees' perception of CSR and its impact on Organizational Commitment (OC) within the mining sector, Although, nowadays there is much literatures written on CSR, limited researches have looked at the impact of perceived CSR on the organizational commitment within the mining sector, and in an emerging economy like DRC. Moreover, In Africa very few researchers have shown interests towards CSR as compared to the Western counterparts. This study empirically tests the relationship between CSR and organizational commitment, whereby the CSR constructs emerged from CSR pyramid developed by (Carroll, 1991) and (Visser, (2008)), and adopted the extended CSR pyramid for mining sector introduced in (Yakovleva and Vazquez-Brust, 2012). which consisted of the five dimensions such as Economic, legal, environmental, ethical and philanthropic, the study revealed that the first three dimensions were significant predictors of organizational commitment.

\section{Literature Review}

\subsection{Corporate Social Responsibility}

The very attempt to the definition of CSR was by (Bowen, 1953 ), who is almost considered as the "Father of corporate social responsibility", and they should therefore have certain obligations to society (Bowen, 1953 ) defined CSR as The obligations of businessmen to pursue those policies, to make decisions, or to follow those lines of action which are desirable in terms of the objectives and values of our society. Later on some scholars, like Frederick (1960), who are influential in the field, criticized Bowen's view, believing that corporations should manage their business operations in order to fulfil the public's expectations and improve socio-economic welfare (Frederick, 1960).

It's obvious that the early 1960 marked the debut of the concept of CSR into the business world, as during this period the firms started engaging in environmental and social activities in most of their business operations, moreover improving the relationship between organizations and stakeholders such as employees, suppliers, customers, however Initially the main concerns of corporate social responsibility were employment equal opportunities, health and safety issues. Nowadays, corporate social responsibility is not just focusing on the health and safety issues but it incorporates Environmental and Ethical matters.

For a clear picture of social responsibility in organizations (Carroll, 1991) developed CSR framework with of four dimensions, in the shape of pyramid, which is widely known as Carroll's pyramid ,Economic responsibilities is treated as the foundation of the pyramid, then followed by legal, ethical and Philanthropic responsibilities. Meanwhile businesses look at the Economic and legal components of the pyramid as the fundamental and required responsibilities, whereas Ethical and philanthropic are described as expected and desired responsibilities, respectively (Schwartz and Carroll 2003). According to (Carroll, 1991), CSR implies that a firm should be incorporate these four dimensions and fulfill them simultaneously, an organization that follows a good CSR policy, ought to fulfill the primary role of business by making profit, ensuring that they are obeying the laws, they are being ethical, and good corporate citizen. Caroll's pyramid holds that all the obligations to the society are addressed in these four dimensions, whereby businesses ought to fulfill these responsibilities all together, failing to achieve that, firms need attempt and improve. Carroll's four-part model has been one of the most influential in the field of CSR.

However Looking at the African side, (Visser, (2008)) stated that, in developing Countries, Corporate social responsibility is less formalized or institutionalized and most of business do not consider social issues as their concern, expecting that, all the social issues are to be solved by the government, like also stated later by (Campbell, 2012) in the study "redefining the roles and responsibilities of public and private actors in the mining sector".

However from caroll's pyramid, (Visser, (2008)) came up with a different order in the CSR pyramid, whereby economic responsibilities still at the foundation of the pyramid,then follow by the philanthropic, ethical then legal responsibilities. 
Both CSR frameworks differ by the order of the dimensions in the pyramid, and furthermore Visser wants to emphasize on raising the need about implementing the philanthropic in these developing countries, such as investing in infrastructure, promoting education by building schools, investing in hospitals and housing. Making an economic contribution through investment, job creation, taxes, and technology transfer is considered as the most important social impact of business. Unfortunately none of the two frameworks outlined the environmental responsibilities of business, meanwhile the environmental issues are critical in developing countries moreover the mining sector.(Carroll, 1991) environmental issues are to be addressed as legal and ethical responsibilities, whereas (Visser, (2008))considered environmental concerns as part of legal, ethical and philanthropic responsibilities. All over the world mining multinationals are increasingly involved in development and promotion of ethical and environmental initiatives through CSR reporting, ethical codes of conduct, global standards in human rights and environmental management.

Therefore considering the responsibilities for the environment within the mining sector, the study adopted the extended CSR pyramid studied (Yakovleva and Vazquez-Brust, 2012), which was also addressing the same sector, however environmental responsibilities will be treated a separate dimension, along with the other, thus CSR in this study consist of five dimensions such as economic, legal, environmental, ethical, and philanthropic.

\subsubsection{Economic responsibilities}

This dimension is treated as the most important, for all the stakeholders, mostly to shareholders, employees and government, whereas community, civil society, do not really benefit from it, as most of the firms are profit oriented, and investing in the social causes, seem to be a lost for them. In DRC for instance, the civil society organizations in particular actively pushed for more clarity on the disbursement of revenues derived from mining royalties. As a result, the 2018 Mining Code modified the mechanism for transferring payments to local governments as set in its article 242, opting for direct payments from companies from July 2018 onwards. Economic responsibilities Involves several aspects for the development such as investing in infrastructure, contracting local suppliers, payment of taxes and royalties, the increase in the employment. The most basic responsibility of a business organization is to maximize its profitability not only to attend to the interests of its shareholders but also to contribute to the progress of the economy. A business is thereby an integral actor in economic development and nation building. The more traditional economic model of corporate social responsibility echoes this role. American economist Milton Friedman once mentioned that prime responsibility of a business is to maximize profits and to ensure that it is able to pay all taxes levied by the government. It is important to note that if a business is unable to produce profitable products and maintain sustainability, it is impossible to attend to all other succeeding social responsibilities. It has been noted that mining brings employment, capital, development, it brings hope and future for marginalized areas of the country.",

\subsubsection{Legal responsibilities}

As argued (Visser, (2008))view of low relative importance of legal responsibilities in developing countries. The Democratic Republic of the Congo, the mining sector had been operating for so many years without having a proper legal framework, absence of strong regulatory enforcement for so many years, It was later then in 2007, when the DRC began implementing the Extractive Industry Transparency Initiative (EITI,) after decades of conflict, political instability, corruption, looting and mineral smuggling had decimated the mining sector, which used to be DRC's engine of growth, and left the government with large liabilities for its state-owned enterprises (SOEs) that had become practically insolvent. However, the new Mining Code includes several provisions related to the traceability of revenues and transparency of the sector. It introduced high fines for companies that do not respect these provisions. The latter include language on the commitment of the government to implement the EITI, the disclosure of revenues and beneficial owners by companies, strengthened transparency around the process for awarding and transferring mining licenses, systematic disclosure of production and export data, public access to all contracts and the publication of audited financial statements by mining companies and state-owned enterprises. 


\subsubsection{Environmental Responsibility}

Looking at the damages and devastating situations that are caused by the mining sector, it is important, having a specific focus on the environmental obligation of business, and studying it more explicitly, will help in enhancing the corporate approach and strategies of the environment. In certain situation, it will be inappropriate, to identify environmental issues with legal responsibilities, researches have shown that most of the emerging countries have weak legal policy, therefore environmental concern might be affected, and placing environmental issues as part of ethical responsibilities, the scope and range of environmental responsibilities can be influenced by local ethical policy that may not include global environmental concerns. The responsibility to be 'environmentally safe' should be firm's responsibility even if there is no economic benefit, community expectation or statutory obligation.

\subsubsection{Ethical Responsibility}

Recognizing that ethical responsibilities, including ethical standards and transparency, are important part of CSR. 'Ideally, CSR means companies have standards and controls internally, rather than waiting for government inspections, and are open about consequences of their undertakings.

The decisions and actions of a business organization affect the stakeholders in several and varied ways. This fact makes it a moral actor. It also gives a business an obligation to follow ethical standards, norms, and values of the communities wherein it operates. An ethically responsible business is able to recognize, interpret, and act upon multiple principles and values according to standards prescribed by a particular context or within a given field. It is able to distinguish right from wrong and make decisions and actions that serve the interests of concerned parties. Several business organizations have adopted a written Code of Conduct to standardize the way managers and employees act or behave within an identified ethical boundary. However, there are businesses that do not have any written code. In this case, managers become the prime moral actors and they base their decisions on their own standards of morality. And for the employer, there is a moral obligation to offer to employees' fair pay and reasonable work expectations, while also providing a safe work environment.

\subsubsection{Philanthropic Responsibility}

This dimension holds that the firm is an active member in contributing to the wellbeing of the society, whereby it implies the philanthropic actions taken by the firms towards the communities, for instance it's the duty of the company to give back to the society, however looking at the damage caused to society by the mining firms, philanthropic responsibility should be more than a duty. Take note that the first three responsibilities are straightforward. Businesses organizations are obligated to fulfil their economic, legal, and ethical obligations in order to ensure their survival. However, the fourth responsibility is not a mandatory. There are businesses that do not have any philanthropic programs. This is especially true for smaller or struggling businesses with limited resources. But over the years, some businesses take pride of their philanthropic works. This responsibility gives them a sense of purpose while also promoting their public image. Of course, philanthropy does not necessarily mean giving cash donations. There are several ways an organization can become philanthropic without spending too much. Some large businesses hold capacity-building seminars for budding and emerging entrepreneurs. Others participate in fund-raising activities.

\subsection{Miners Commitment}

In this research, Miners commitment is simply the Organizational commitment, whereby most of the researches, have considered the emotional commitment in investigating the impact of CSR on employee attitudes (Stephen Brammer et al., 2007; Kim et al., 2016; Lee, Kim, Lee, and Li, 2012; Peterson, 2004). The concept of emotional commitment with the organization is an important concept that attracted many researchers, as it corresponds to the fact that employees see, or not, their future linked to that of the organization, and are willing to make sacrifices for this. Organizational commitment has therefore a strong influence on employee behavior and performance at work. Emotional engagement refers to the identification and involvement of an individual based on his emotions towards the organization (Allen and Meyer 1990). 
However, Organizational Commitment is how employees affiliate themselves to their organization, a concept that is commonly studied in organizational behavior. On the other hand, Porter and Steers in 1982, argued that Emotional commitment is a belief and acceptance of the goals and values of organization, a willingness to make a considerable effort towards the organization and a desire to strong to maintain a membership to it. Organizational Commitment has been related to valuable outcomes for both employees and employers that could result in enhanced feelings of belonging, security, efficacy, greater career advancement, increased compensation, and increased intrinsic rewards for the individual. Therefore, many researchers consider the organizational commitment as a significant concept, in understanding how attached employees are with the organizations with respect to the performance and effectiveness at work. Furthermore, it even intervenes in the social and welfare of the employees as well as their personal development within the organization. However (Meyer and Allen 1991) the pioneer of the organizational commitment model, they insisted that the level of implications depends on the different components of commitment. Whereby they divided the organizational commitment in the three dimensions such as affective commitment, continuance commitment and normative commitment. However, in most researches, which treated with the organizational commitment, the affective component had been given much attention, as the organizational commitment in exploring its outcomes for employees or organizations. As affective commitment is an employee's emotional attachment to, identification with, and involvement with the organization as well as enjoyment of being a member of the organization.

\subsection{CSR and organizational commitment}

Studies have been conducted, various have looked at this relationship from different angles ad perspectives, in certain researches, scholars portrayed a direct relationship between the two constructs, whereas some believed that additional factors should considered as mediation in this relationship, furthermore for some group researchers the demographic profile of employees plays a moderation role in the relationship between their perceptions of CSR and their commitment with the organization. In this regard (Roudaki and Arslan, 2017) conducted a study on the impact of perceived CSR on the Organizational Commitment (OC) their study was done in the service sector ,however CSR was measured through the four dimensions economic, legal, ethical and philanthropic. In this study the results from correlation and regression analysis illustrated that there is positive relation between CSR and organizational commitment, this study was based on 220 employees in the hospitality sector.(Closon et al., 2015) their study exploring the effects of CSR on the organizational outcomes, the research illustrated a positive relationship between CSR and organizational commitment meanwhile, this study considered mediation effect whereby employ engagement and CSR values were the mediators, identified mediators affects this relationship, and that the effect is stronger when both mediators are included in the model.

(Farooq, Payaud, Merunka, and Valette-Florence, 2014) treated affective commitment as the whole organizational commitment, in studying the impact of CSR on organizational commitment however the test was done using structural equation modelling, meanwhile referring from the social exchange theory and the social identity, the researches considered organizational trust and organizational identification as the mediators in this relationship ,the study was done on sample of 378 employees. Consequently, this increases the commitment and loyalty of employees within the organizations and they feel the honor to be a part of such organization. Moreover, (Y, S, and SY, 2010) argued that environment of social and ethical responsibility promotes organizational commitment through the exchange of relationships between employees.(Peterson, 2004)demonstrated that perceived CSR such as organizational ethics and discretionary initiatives were significant and positively related to organizational commitment particularly, and at the other side (S Brammer et al., 2007) concluded that, the perceptions of employees that their company is a responsible member of the community can have an impact on the business. (Turker, 2009) found a positive relationship between CSR and organizational commitment and also documented an increase in employee perception.

Literature provides support to the argument that employees of ethically and socially responsible organizations may incline more value and recognition towards their organization. Consequently, this increases the commitment and loyalty of employees within the organizations and they feel the honor to be a part of such organization. Moreover, argued that environment of social and ethical responsibility promotes organizational commitment through the exchange of relationships between employees. Perceptions of CSR have a positive relationship with employee 
commitment (S Brammer et al., 2007; Kim et al., 2016; Roudaki and Arslan, 2017; Shin et al., 2016). Employee perceptions of CSR can be influenced by external CSR (programs and actions that affect external stakeholders) as well as internal CSR (how the company treats its workforce). External CSR includes actions such as philanthropy and social contributions, treatment of the physical environment and the extent of ethical behavior toward consumers and other stakeholders. Perceptions of CSR are also influenced by public reputation of the company as well as media, more specifically, employees' perceptions of the company's public reputation.

\subsection{Measurements} Independent variables (IV)

Perceived CSR refers to the degree of employees' perception about the support provided by their employer to the CSR-related activities. The survey of literature indicates that most studies have used employee or customer perception to measure CSR (Lee et al., 2012) specifically measures four distinct constructs, economic, legal, ethical and philanthropic, whereby in this study, CSR was measured by five constructs, including environmental dimension, however the overall CSR construct have 20 items adopted from the previous researches on ${ }^{\text {ee }}$ perceptions of CSR adapted within the mining sector (Yakovleva and Vazquez-Brust, 2012) It was measures on the five-point Likert scale from "strongly disagree to strongly agree".

\section{Dependent variable (DV)}

Employees' commitment was measured based on the affective component of organizational commitment. Whereby, the organizational commitment was measured with using a nine-item shortened version of the 15-item Organizational Commitment Questionnaire (OCQ). (Mowday et al., 1979). The selected scale is one of the most frequently used and reliable measure of affective commitment and responses are obtained on a five-point Likerttype scale from strongly agree to strongly disagree. the same scale was adapted by (Turker, 2009) in studying the impact of CSR on the organizational commitment .

H1: There is a positive relationship between Economic CSR and Organizational commitment

$H_{2}$ : There is a positive relationship between Legal CSR and Organizational commitment.

H3: $H_{2}$ : There is a positive relationship between Legal CSR and Organizational commitment.

$H_{4}$ There is a positive relationship between Ethical CSR and Organizational commitment

$H_{5:}$ There is a positive relationship between Philanthropic CSR and Organizational commitment

\section{METHODOLOGY}

\subsection{Data Collection Sample}

This work targeted a population of workers, within the mining sector of the Democratic Republic of Congo. A questionnaire was designed, and distributed using Google forms, a target sample of 450, workers from different mining region across the country, however 415 questionnaires were successfully submitted in a period of 3 weeks, therefore 415 was the final number of the questionnaires to be analyzed. $38.8 \%$ of respondents were females whereas $61.2 \%$ were males, it clearly highlights that, and the DRC mining sector is dominated by men workers, $49.7 \%$ of Respondents were 50 years old and below, whereas $50.3 \%$ were above 50 years old, and looking at the education level, $46.5 \%$ have diploma and 14.7\% have first degree, 38.8\% have second degree. And above all, tenure is an important aspect to consider in the organizational commitment, however 75.2 of the workers have more than five years' experience with their organization, $24.8 \%$ have 2 years and less. 


\section{Model specification}

In this study, a linear regression was carried in order to determine the linear relationships between variables. However, the equation (1) is expressing the linear relationships between one dependent variable and five independent variables.

\section{$Y=\alpha+\beta_{1} X_{1}+\beta_{2} X_{2}+\beta_{3} X_{3}+\beta_{4} X_{4}+\beta_{5} X_{5}(1)$}

In this equation, $\hat{y}$ is the predicted value of the dependent variable (AOC). Values of the independent variables (ECO_CSR, LEG_CSR, ENV_CSR, ETHIC_CSR, PHIL_CSR) are denoted by x1, X2, X3, X4, X5. The slope betas represent the regression coefficients, whereas alpha is the intercept.

\section{ANALYSIS AND RESULTS}

Table 1 shows the internal consistency, whereby factor analysis were conducted for each scale, for all the five independents variables, the items loaded successfully, meanwhile for the dependent variables, six items out nine loaded, whereas 3 items were deleted. the internal consistency for each scale was calculated, whereby for all the however the Cronbach's Alpha for all the constructs were satisfying, the lowest was 0.7 and the highest was 0.89.As suggested by (Cronbach, 1951; Taber, 2018).

Table 1: Constructs and Internal Consistency Reliability

\begin{tabular}{|c|c|c|c|}
\hline CONSTRUCT & ITEMS & LOADINGS & CRONBACH'ALPHA \\
\hline \multirow{4}{*}{ ECO_CSR } & ECO1 & 0.946 & \multirow{4}{*}{0.71} \\
\hline & $\mathrm{ECO} 2$ & 0.937 & \\
\hline & $\mathrm{ECO} 3$ & 0.266 & \\
\hline & $\mathrm{ECO} 4$ & 0.785 & \\
\hline \multirow{4}{*}{ LEG_CSR } & LEG1 & 0.944 & \multirow{4}{*}{0.76} \\
\hline & LEG2 & 0.183 & \\
\hline & LEG3 & 0.957 & \\
\hline & LEG4 & 0.827 & \\
\hline \multirow{4}{*}{ ENV_CSR } & ENV1 & 0.986 & \multirow{4}{*}{0.87} \\
\hline & ENV2 & 0.987 & \\
\hline & ENV3 & 0.978 & \\
\hline & ENV4 & 0.430 & \\
\hline \multirow{4}{*}{ ETHIC_CSR } & ETHIC1 & 0.938 & \multirow{4}{*}{0.76} \\
\hline & ETHIC2 & 0.949 & \\
\hline & ETHIC3 & 0.943 & \\
\hline & ETHIC4 & 0.858 & \\
\hline \multirow{4}{*}{ PHIL_CSR } & PHIL 1 & 0.845 & \multirow{4}{*}{0.7} \\
\hline & PHIL2 & 0.899 & \\
\hline & PHIL3 & 0.838 & \\
\hline & PHIL4 & 0.979 & \\
\hline & $\mathrm{AOC1}$ & 0.944 & 0.89 \\
\hline
\end{tabular}




$\begin{array}{lll}\text { AOC2 } & 0.958 \\ \text { AOC4 } & 0.436 \\ \text { AOC } 6 & 0.936 \\ \text { AOC7 } & 0.966 \\ \text { AOC9 } & 0.356\end{array}$

ECO_CSR: The economic dimension of corporate social Responsibility

Leg_CSR: The Legal dimension of corporate social Responsibility

Env_CSR: The environmental dimension of corporate social Responsibility

ETHIC_CSR: The ethical dimension of corporate social Responsibility

PHIL_CSR: The philanthropic dimension of corporate social Responsibility

AOC: Affective Organizational Commitment.

The Appendix 1 illustrates the descriptive statistics and correlation coefficients among the variables. Whereas, the results depict that, the independent, the control variables as well the dependent variable are correlated, however the affective commitment (AOC) is positively correlated with Economic CSR (ECO_CSR), legal CSR (Leg_CSR) and Environmental CSR (ENV_CSR). Whereby prior research in the service sector found that the four dimensions CSR was having positive correlation with Organizational commitment; however, it shows that Workers commitment is highly linked to the economic, legal and environmental values.

The Table 2 shows the findings of the regression analysis, that was carried on, however the Model M in table 2 presented a satisfying explaining power, on looking at the relationship between CSR dimensions and the commitment of the employees, the adjusted $\mathrm{R}^{2}$ of $87 \%$, depicts that only $13 \%$ of data concerning this relationship is remained unexplained. The overall explanatory power of the models is satisfactory within the context of a crosssection study; R2 is greater than 0.60 in each model and the F statistic is highly significant in each case. Taken together, the results show that the 4 first dimensions of CSR contributes significantly to the organizational commitment and however, four hypothesized relationships are supported and explained by this model, only Philanthropic was found to be insignificant.

Table 2: REGRESSION ON CSR DIMENSIONS ON AFFECTIVE ORGANIZATIONAL COMMITMENT

$\begin{array}{llllll}\text { AOC } & \text { Beta }(\beta) & \text { T_VALUE } & \text { P_VALUE } & \text { HYPOTHESIS } & \\ & \text { MODEL } & & & & \\ \text { ECO_CSR } & 0.21 & 6.92 & 0.030 & \text { H1 } & \text { ACCEPTED } \\ \text { LEG_CSR } & 0.26 & 7.04 & 0.036 & \text { H2 } & \text { ACCEPTED } \\ \text { ENV_CSR } & 0.46 & 13.29 & 0.035 & \text { H3 } & \text { ACCEPTED } \\ \text { ETHIC_CSR } & -0.15 & -7.38 & 0.021 & \text { H4 } & \text { REJECTED } \\ \text { PHIL_CSR } & -0.00015 & -0.063 & 0.023 & \text { H5 } & \text { REJECTED } \\ \text { Error } & 0.022 & 14.30 & 0.0015 & & \\ \mathrm{R}^{2} & 0.93 & & & & \end{array}$


The above results (Model M) provide substantial support for a significant relationship between CSR and organizational commitment. ECO_CSR, LEG_CSR, ENV_CSR and ETHIC_CSR are significant (p, 0.05) and $(\mathrm{t}>2)$. Whereas, ECO_CSR, LEG_CSR and ENV_CSR presented a positive and significant relationship, whereby $\mathrm{H}_{1}, \mathrm{H}_{2}$ and $\mathrm{H}_{3}$ are supported. Therefore Economic responsibility (ECO_CSR) of the mining sector is positively and significantly related to organizational commitment as the slope $(\beta=0.21)$ is the positive change in commitment of the workers in relation with the perceived economic responsibility of the firm, secondly the legal responsibility is found to be positively and significantly related to the organizational commitment, whereby the slope ( $\beta=0.26)$ is the increase that occurs in the commitment of the worker, once the employees perceive improvement of the legal responsibility of their firm, and lastly environmental responsibility is similarly having a significant and positive impact on the commitment of the workers of the mining sector, as the slope $(\beta=0.46)$ is the increase in commitment when employees have high perception of environmental responsibility, which means the more mining firms are improving their environmental policies ,the more the commitment of their workers will be enhanced, Ethical responsibility presented a negative impact, the perception of the ethical responsibility that employees have for their organization is not impacting their commitment, furthermore the philanthropic responsibility is insignificant , Looking at the needs of the workers within this sector, it seems they are less interested by the philanthropic initiatives, as these are more external activities that the firms carry, which probably employees do not see their interests in it, meanwhile firms should consider other stakeholders that might be affected . Not performing and or not having good policy to benefit the society and the community ,mining firms are just confirming what (Campbell, 2012; Visser, (2008)) stated that in emerging economies, business expect the government to pay this role. for instance a lot can be deducted from the insignificance of the philanthropic dimension, Workers might have low perceptions of the philanthropic responsibilities of their organization, if the organization do not have good policy about this dimension, neither activities to support the well-being of the society but as long as employees basic needs are being met, they remain committed, and they look at the philanthropic dimension as external to the organization, however it does not affect their commitment.

\section{Figure 1. REGRESSION PATH}

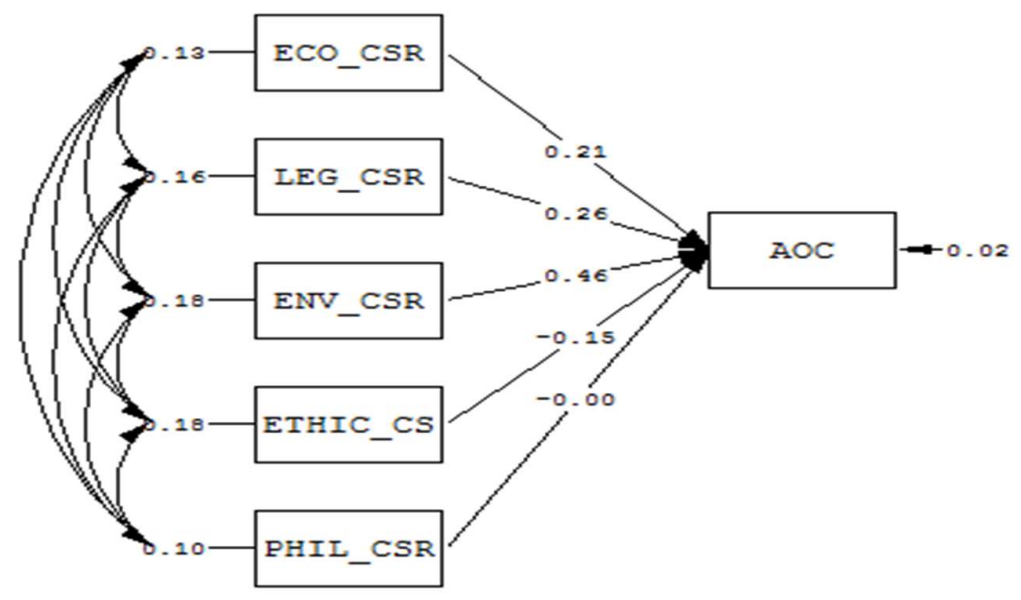

And the Figure 1. shows the regression path with the coefficients of the five distinctive dimensions of CSR in the relationship with the affective commitment, the path was done using structural equation modelling through LISREL 8.70. generally, LISREL applies different algorithm than the one used in the linear regression. And the coefficients found by LISREL are very similar to the results found in the table 2 regression using spss which indicate the strength of the statistical relationships. However, the findings in Figure 1. support the findings in table 2 , and $\mathrm{R}^{2}$ is equivalent. The Figure 1. depicts the relationships between the dimensions of CSR and the commitment of the employees using paths.

\section{CONCLUSION}

The study focused on the relationship between the dimensions CSR and Organizational commitment, whereby, five dimensions were adapted to fit the mining sector. This research has illustrated that the perceptions of Mining 
CSR practices would increase the commitment of the employees. The results revealed that out five CSR dimensions, three dimensions of CSR have positive and significant impact on the commitment of the workers. Prior researches support the findings, that, there is a significant relationship between CSR and Organizational commitment. The mining workers are committed if their organizations fulfill some of the CSR practices. As workers recognize the significance of CSR; the present study analyzed the effect of perceived CSR on organizational commitment in the mining sector of DRC. Specifically, the focus of the study was to examine the nexus between the five dimensions of mining CSR and organizational commitment of the workers.

Findings have revealed that the perception of the Economic Responsibility, that the workers have of their organization influence their commitment, and the effect is positive and significant. As long as a firm is able to create economic value for its stakeholders, for instance their employees become more and more attached to the firm. The perception of the Legal responsibility that employee have for this sector, also is good predictor of their commitment, the results showed a significant and positive effect on the commitment, Employees are highly concerned about firms, that follow the regulations, and abide to the rules of the land, furthermore the well-being of labor is the results of good legal policy within the sector.

Environmental Responsibility in this research was treated as a different dimension, whereas it's generally comes in legal and ethical dimensions, environmental issues are addresses by the legal and ethical responsibilities, from the CSR framework, but in this research an extended CSR framework was adapted to be more specific to the mining sector, however environmental issues were address as separate dimensions of the CSR framework. The results revealed high positive and significant effect of the perception of environmental responsibility to the commitment of the workers, employees are committed as they see the organization to which belong, following and including environmental policies to their operations, in this era of global warming, everyone has become sensitive to the matters regarding the environmental protection, mining workers for instance are emotionally attached to the organization that support the environmental values, and that lower their the impact of the operations to the soil, water and air. Ethical responsibility in itself was weak, but since it's known that in general environmental issues are address as ethical, the conclusion this, employee's attention is much about how ethic the firm operates in their operations vis a vis of the environment.

Philanthropic was insignificant, workers in this sector, have low perceptions of philanthropic activities, considering the country of the study, firms still need to implement and reinforce their social policy, Although this dimension is not impacting the commitment of the workers, it might because employees are much concerned about what goes internally the firms, whereas Philanthropic is more of an external, mining firms in the DRC have more to do , and design initiative that support the communities and contribute to the well-being of the Society as well as philanthropic activities such as "contributing towards the betterment of community" and "helping poor people". Overall, the above statements confirm also a number of previous studies that investigated the relationship between Corporate Social Responsibility and employee commitment. (Albinger, Freeman, 2000, Peterson, 2004). Therefore, it is reasonable to state that firms that implement CSR initiatives will tend to a positive relationship with their employees, and follow they are more probably to acquire employees' commitment than companies that do not take care about CSR activities. One of the objectives of the organization is to provide the necessary tools that make professional and personal development possible for each worker, consequently guaranteeing a better quality of life. However, if CSR can enhance the commitment in the work place then it's the way to go for organizations, the positive effect of CSR on human resource management, organizations with well-designed strategy of human resource, which is CSR oriented, would increase the chance to have employee who are very motivated and with good work performance.

The findings suggest that HR managers should consider CSR activities in communication, resource management, and strategy management to enhance commitment and ultimately performance [47]. Moreover, CSR activities and positive working conditions not only help to retain and attract talented individuals but also increase the level of commitment and identification with their firms. The findings of the present study revealed that service sector companies should not avoid CSR activities, especially hotels, as this may help to boost their image and attract talented employees and customers. One of the key problems of current research is the limited literatures and empirical researches about the impact CSR has on employees within the mining sector. The scholars have not yet 
reached a consensus on how CSR affects the workers within the mining industry. This lack could be partly due to problems associated with adapting the CSR framework to fit the mining industry. At the hand, it's the key benefit of this paper, adding to the literature review which creates a research framework that could be used for subsequent analysis of links between CSR and employees with the mining sector, in the Democratic Republic of Congo. CSR is still relatively new direction of long-term management of the organization. Most probably, we will be able to appreciate the impacts of CSR in a longer time period, therefore further research is needed.

\section{LIMITATIONS TO THE RESEARCH}

The main limitation was in reaching out the respondents, the questionnaire was distributed electronically and share among employees, whereby some of the workers were not very familiar, with technology, some will get bored in filling the forms, and will remain uncompleted, however there will be a need for improvement, in the next research, as in DRC most of the mining sites are located in these remote areas whereby.. Despite all the above limitations, the analyzes have been successfully completed in producing significant results. These, however, are not generalizable to other sectors than the mining sectors, because even if at the level of the specific sector as such, the results seem representative, it would be necessary, in order to generalize them, to have a larger sample of answers including various sectors. And reduce the previously mentioned bias. However, in regards to this we strongly encourage for further studies on the perceptions of employees in other different sectors.

\section{Authors Contributions}

The main work was done by Grace Mulindwa Bahizire from Reviewing and Analysis under the supervisory of Li Fanglin (Professor); Raha Bahizire Benjamin contributed in reaching out and questionnaire Analysis.

\section{Funding Institution}

The research work was fully supported by the National Natural Science Foundation of China and the grant number 71503105 .

\section{Disclosure Statement}

Concerning the realization of this work I declare that there is no conflict of interest that was noted

\section{REFERENCES}

Andrews, N. (2016). Challenges of corporate social responsibility (CSR) in domestic settings: An exploration of mining regulation vis-à-vis CSR in Ghana. Resources Policy, 47, 9-17. doi: https://doi.org/10.1016/j.resourpol.2015.11.001

Asrar-ul-Haq, M., Kuchinke, K. P., and Iqbal, A. (2017). The relationship between corporate social responsibility, job satisfaction, and organizational commitment: Case of Pakistani higher education. Journal of cleaner production, 142, 2352-2363.

Bouraoui, K., Bensemmane, S., Ohana, M., and Russo, M. (2019). Corporate social responsibility and employees' affective commitment: A multiple mediation model. Management Decision, 57(1), 152-167.

Bowen, H. R. (1953 ). Social responsibilities of the businessman New York: Harper.

Brammer, S., Millington, A., and Rayton, B. (2007). The contribution of corporate social responsibility to organizational commitment. The International Journal of Human Resource Management, 18(10), 17011719.

Brammer, S., Millington, A., and Rayton, B. (2007). The contribution of corporate social responsibility to organizational commitment. International Journal of Human Resource Management, 18(10), 1701-1719.

Campbell, B. (2012). Corporate Social Responsibility and development in Africa: Redefining the roles and responsibilities of public and private actors in the mining sector. Resources Policy, 37(2), 138-143.

Carroll, A. B. (1991). The pyramid of corporate social responsibility: Toward the moral management of organizational stakeholders. Business Horizons, 34(4), 39-48. doi: https://doi.org/10.1016/00076813(91)90005-G 
Closon, C., Leys, C., and Hellemans, C. (2015). Perceptions of corporate social responsibility, organizational commitment and job satisfaction. Management Research: The Journal of the Iberoamerican Academy of Management, 13(1), 31-54.

Cronbach, L. (1951). Coefficient alpha and the internal structure of tests. Psychometrika, 16(3), 297-334.

Fanglin, L., Bahizire, G. M., and Benjamin, R. B. (2019). The effect of employees 'perceptions of CSR on

Job satisfaction: a mediation analysis with SEM. International Journal of Economics, Commerce and Management, VII(5), 14.

Farooq, O., Payaud, M., Merunka, D., and Valette-Florence, P. (2014). The Impact of Corporate Social Responsibility on Organizational Commitment: Exploring Multiple Mediation Mechanisms. Journal of Business Ethics, 125(4), 563-580.

Frederick, W. C. (1960). The growing concern over business responsibility. California Management Review 2 54-61.

Garrett, N., and Lintzer, M. (2010). Can Katanga's mining sector drive growth and development in the DRC? Journal of Eastern African Studies, 4(3), 400-424. doi: 10.1080/17531055.2010.517408

Geenen, S. (2014). Dispossession, displacement and resistance: Artisanal miners in a gold concession in SouthKivu, Democratic Republic of Congo. Resources Policy, 40, 90-99. doi: https://doi.org/10.1016/j.resourpol.2013.03.004

Glavas, A., and Kelley, K. (2015). The Effects of Perceived Corporate Social Responsibility on Employee Attitudes. Business Ethics Quarterly, 24(2), 165-202. doi: 10.5840/beq20143206

Herrera Madueño, J., Larrán Jorge, M., Martínez Conesa, I., and Martínez-Martínez, D. (2016). Relationship between corporate social responsibility and competitive performance in Spanish SMEs: Empirical evidence from a stakeholders' perspective. BRQ Business Research Quarterly, 19(1), 55-72. doi: https://doi.org/10.1016/j.brq.2015.06.002

Kim, J., Song, H. J., and Lee, C.-K. (2016). Effects of corporate social responsibility and internal marketing on organizational commitment and turnover intentions. International Journal of Hospitality Management, 55, 25-32. doi: https://doi.org/10.1016/j.ijhm.2016.02.007

Lee, Y.-K., Kim, Y. S., Lee, K. H., and Li, D.-x. (2012). The impact of CSR on relationship quality and relationship outcomes: A perspective of service employees. International Journal of Hospitality Management, 31(3), 745-756. doi: https://doi.org/10.1016/j.ijhm.2011.09.011

Maqbool, S., and Zameer, M. N. (2018). Corporate social responsibility and financial performance: An empirical analysis of Indian banks. Future Business Journal, 4(1), 84-93. doi: https://doi.org/10.1016/j.fbj.2017.12.002

Mutti, D., Yakovleva, N., Diego, V.-B., and Di Marco, M. H. (2012). Corporate social responsibility in the mining industry: Perspectives from stakeholder groups in Argentina. Resources Policy, 37(2), 212-222.

Peterson, D. K. (2004). The Relationship between Perceptions of Corporate Citizenship and Organizational Commitment. Business and Society, 43(3), 296-319. doi: 10.1177/0007650304268065

Rodrigues, M., and Mendes, L. (2018). Mapping of the literature on social responsibility in the mining industry: A systematic literature review. Journal of Cleaner Production, 181, 88-101. doi: https://doi.org/10.1016/j.jclepro.2018.01.163

Rodriguez-Fernandez, M. (2016). Social responsibility and financial performance: The role of good corporate governance. BRQ Business Research Quarterly, 19(2), 137-151. doi: https://doi.org/10.1016/j.brq.2015.08.001

Roudaki, J., and Arslan, M. (2017). Impact of Perceived CSR on Organizational Commitment: A Perspective of Service Employees (Vol. 1).

Shin, I., Hur, W.-M., and Kang, S. (2016). Employees' Perceptions of Corporate Social Responsibility and Job Performance: A Sequential Mediation Model. Sustainability, 8(5), 493.

Taber, K. S. (2018). The Use of Cronbach's Alpha When Developing and Reporting Research Instruments in Science Education. Research in Science Education, 48(6), 1273-1296. doi: 10.1007/s11165-016-9602-2

Turker, D. (2009). How corporate social responsibility influences organizational commitment. Journal of Business ethics, 89(2), 189. 
Visser, W. ( (2008)). Corporate Social Responsibility in Developing Countries (A. M. In A. Crane, D. Matten, J. Moon and D. Siegel Ed.): Oxford: Oxford University Press,.

Y, G., S, C., and SY, C. ( 2010). High performance work system and collective OCB: A collective social exchange perspective. Human Resource Management Journal., 20 119-137.

Yakovleva, N., and Vazquez-Brust, D. (2012). Stakeholder Perspectives on CSR of Mining MNCs in Argentina. Journal of Business ethics, 106(2), 191-211.

APPENDIX

Appendix 1: Descriptive statistics and Correlations

\begin{tabular}{|c|c|c|c|c|c|c|c|c|c|c|c|c|}
\hline Variables & Mean & Std. Deviation & gender & age & tenure & Education & ECO_CSR & LEG_CSR & ENV_CSR & ETHIC_CSR & PHIL_CSR & $\mathrm{AOC}$ \\
\hline gender & 1.3880 & 0.48787 & 1 & & & & & & & & & \\
\hline age & 3.2940 & 1.50854 & $-.536^{* *}$ & 1 & & & & & & & & \\
\hline education & 2.9229 & 0.92147 & -0.019 & $.631^{* *}$ & $.576^{* *}$ & 1 & & & & & & \\
\hline ECO_CSR & 4.3729 & 0.36732 & $-.607^{* *}$ & $.768^{* *}$ & $.462^{* *}$ & $.588^{* *}$ & 1 & & & & & \\
\hline ENV_CSR & 3.0837 & 0.42642 & $-.752^{* *}$ & $.813^{* *}$ & $.555^{* \varepsilon}$ & $.245^{* *}$ & $.724^{* *}$ & $.842^{* *}$ & 1 & & & \\
\hline ETHIC_CSR & 3.4747 & 0.42095 & $.386^{* *}$ & $-.541^{* *}$ & $-.565^{* *}$ & -0.089 & $-.249^{* *}$ & $-.521^{* *}$ & $-.464^{* *}$ & 1 & & \\
\hline PHIL_CSR & 3.0151 & 0.31792 & 0.005 & 0.000 & 0.032 & $-.109^{*}$ & -0.029 & 0.080 & 0.049 & -0.055 & 1 & \\
\hline
\end{tabular}

